\title{
Benchmarks
}

Identification of newly transcribed RNA, p. 4.10.1-4.10.11. In K. Janssen (Series Ed.), Current Protocols in Molecular Biology, Vol. 1. John Wiley \& Sons, New York.

4.Olnes, M.J. and R.N. Kurl. 1994. Isolation of nuclear extracts from fragile cells: a simplified procedure applied to thymocytes. BioTechniques 17:828-829.

Address correspondence to N. Elango, GRECC (182), Audie L. Murphy Div., South Texas Veterans Health Care System, 7400 Merton Minter Blvd., San Antonio, TX 78284, USA. Internet: elangon@uthscsa. dcci.com

Received 16 October 1996; accepted 13 March 1997.

Narayanasamy Elango, Jeevalatha Vivekananda, Randy Strong and Michael S. Katz University of Texas Health Science Center at San Antonio

South Texas Veterans Health Care System San Antonio, TX, USA

\section{Ammonium Acetate Pro- tocol for the Preparation of Plasmid DNA Suitable for Mammalian Cell Transfections}

BioTechniques 23:424-427 (September 1997)

Recent progress in human genetics research has resulted in the identification of many new genes whose functions are largely unknown. To characterize these genes and their protein products, expression experiments in mammalian cells represent a logical next step. The introduction and expression of genes in mammalian cells requires successful transduction of DNA. This can be accomplished by a variety of methods, including viral infection and plasmid DNA transfection. Plasmid DNA transfection of tissue culture cells has generally used one of four techniques: (i) calcium phosphate transfection (2,9), (ii) diethyl aminoethyl (DEAE)-dextran transfection, (iii) electroporation (1,3) and (iv) liposome-mediated transfection $(4,7)$. One of the critical parameters inherent in all techniques is the availability of high-quality, pure DNA. Typically, high-quality DNA is obtained using cesium chloride/ethidium bromide ultracentrifugation or anion-exchange resins (5). Cesium chloride banding requires the use of an ultracentrifuge, is rather timeconsuming and involves expensive, toxic reagents. Anion-exchange resin chromatography, on the other hand, does not require an ultracentrifuge and can usually be accomplished in several hours. However, the resin columns are expensive and have maximal capacities, limiting the final yield of DNA. We describe a rapid, low-cost and nontoxic protocol for obtaining large quantities of plasmid DNA suitable for the transfection of mammalian cells.

The procedure used in our laboratory is a modification of the protocol reported by Lee and Rasheed (6). We adapted this protocol for large-scale DNA preparation and increased the solution 1 incubation time from 5-20 min to increase the yield of plasmid DNA. In brief, plasmid DNA is prepared from bacterial cultures grown overnight in LB broth containing $100 \mu \mathrm{g} / \mathrm{mL}$ ampicillin. Typically, bacterial cultures are allowed to achieve log growth by inoculating 2-3 $\mathrm{mL}$ of LB broth with ampicillin for $6-8 \mathrm{~h}$. This growing culture is diluted 1:100 into $250 \mathrm{~mL}$ fresh LB containing ampicillin overnight at $37^{\circ} \mathrm{C}$. Bacteria are collected by centrifugation the next morning for $5 \mathrm{~min}$ at $10000 \times g$ at $4^{\circ} \mathrm{C}$. The resulting bacterial cell pellet is resuspended in $6 \mathrm{~mL}$ of freshly made solution $1(150 \mu \mathrm{L} 1.0$ $\mathrm{M}$ Tris- $\mathrm{HCl}, \mathrm{pH} 7.6,120 \mu \mathrm{L} 0.5 \mathrm{M}$ EDTA, pH 8.0, $600 \mu \mathrm{L} 0.5 \mathrm{M}$ glucose, $12 \mathrm{mg}$ hen egg lysozyme, $5.1 \mathrm{~mL}$ of sterile, deionized water) and incubated on ice for $20 \mathrm{~min}$. Next, $12 \mathrm{~mL}$ of freshly prepared solution $2(600 \mu \mathrm{L}$ $20 \%$ sodium dodecyl sulfate [SDS], $480 \mu \mathrm{L} 5.0 \mathrm{M} \mathrm{NaOH}, 10.92 \mathrm{~mL}$ of sterile, deionized water) are added. Samples are mixed by inversion and incubated on ice for $10 \mathrm{~min}$. Finally, $9 \mathrm{~mL}$ of ice-cold 7.5 M ammonium acetate $(\mathrm{pH}$ 7.6) are added. The sample is mixed by inversion and particulate matter broken up by vigorous shaking for 5-10 s prior to another 10-min incubation on ice. Centrifugation is accomplished at $10000 \times g$ for $10 \mathrm{~min}$ at $4^{\circ} \mathrm{C}$ in a refrigerated centrifuge. After centrifugation, the supernatant is transferred to a fresh tube, and 0.6 vol of isopropanol is added. Samples are mixed by inversion and incubated for $10 \mathrm{~min}$ at room temperature prior to centrifugation at $10000 \times \mathrm{g}$ for $10 \mathrm{~min}$ at $4^{\circ} \mathrm{C}$ in a refrigerated centrifuge. After centrifugation, the pellet (containing crude plasmid DNA) is resuspended in $4 \mathrm{~mL}$ of $2.0 \mathrm{M}$ ammonium acetate $(\mathrm{pH}$ 7.4) by gentle rocking and incubated on ice for $10 \mathrm{~min}$. Centrifugation is again performed at $10000 \times g$ for $10 \mathrm{~min}$ at $4^{\circ} \mathrm{C}$ in a refrigerated centrifuge. After centrifugation, the supernatant is placed in a fresh tube, and $4 \mathrm{~mL}$ of isopropanol are added, mixed by inversion and incubated at room temperature for $10 \mathrm{~min}$. Centrifugation is performed at $10000 \times g$ for $10 \mathrm{~min}$ at $4^{\circ} \mathrm{C}$ in a refrigerated centrifuge. The final DNA pellet is resuspended in $2 \mathrm{~mL}$ of sterile, deionized water, and $10 \mu \mathrm{L}$ of 5$\mathrm{mg} / \mathrm{mL}$ RNase are added for $20 \mathrm{~min}$ at $37^{\circ} \mathrm{C}$. Following RNase treatment, 1 $\mathrm{mL}$ of ice-cold $7.5 \mathrm{M}$ ammonium acetate ( $\mathrm{pH} 7.6)$ is added and the sample 
mixed by inversion. The sample is then incubated at room temperature for 5 min followed by centrifugation at $10000 \times g$ for $10 \mathrm{~min}$ at room temperature. The supernatant is transferred to a new tube, and $3 \mathrm{~mL}$ of isopropanol are added, mixed by inversion and incubated at room temperature for $10 \mathrm{~min}$. Centrifugation is performed at $10000 \times$ $g$ for $10 \mathrm{~min}$ at room temperature, the resulting pellet washed with $70 \%$ ethanol and resuspended in sterile, deionized water for future use.

DNA prepared using anion-exchange chromatography using the protocol of Qiagen (Chatsworth, CA, USA) was compared to DNA purified using the above ammonium acetate protocol. The anion-exchange protocol was performed in $2 \mathrm{~h}$ while the ammonium acetate protocol took $2.5-3 \mathrm{~h}$ to perform. The maximum yield from the QIAGEN $^{\circledR}$-tip 500 Column ranged from $250-300 \mu \mathrm{g}$ of DNA per $100 \mathrm{~mL}$ culture while the ammonium acetate protocol yielded from 750-5000 $\mu \mathrm{g}$ of DNA per $100 \mathrm{~mL}$ culture using highcopy-number plasmids (pUC19 or pBluescript ${ }^{\circledR}$-based plasmids [Stratagene, La Jolla, CA, USA]), as determined by ethidium bromide staining of DNA separated by agarose gel electrophoresis. DNA obtained by both methods was digested with EcoRI endonuclease and separated by electrophoresis on a $1.0 \%$ agarose gel. The quality of the DNA was similar with both methods (Figure 1A).

To determine whether the DNA obtained by the ammonium acetate method were suitable for the transfection of mammalian cells, both COS-1 and NIH-3T3 cells were transfected using LipofectAMINETM (Life Technologies, Gaithersburg, MD, USA) as previously described by our laboratory (8). Briefly, $1 \mu \mathrm{g}$ of DNA (pcDNA3. NF2.C-term) was mixed in serum-free Dulbecco's modified Eagle medium (DMEM) with $6 \mu \mathrm{L}$ of LIPOFECTAMINE reagent for each well in a 6well plate. COS-1 cells were split the day before into 6-well plates to achieve $70 \%-80 \%$ confluency at the time of transfection. After $6 \mathrm{~h}$ of LIPOFECTAMINE-mediated DNA transfection, fresh DMEM containing 10\% fetal bovine serum and $1 \%$ penicillin-streptomycin was added and the cultures 
returned to the incubator at $37^{\circ} \mathrm{C}$. After $48 \mathrm{~h}$, transfected COS-1 cells were washed twice in phosphate-buffered saline (PBS; pH 7.0) and harvested by scraping into microcentrifuge tubes. Cells were pelleted in a microcentrifuge and lysed in $1 \times$ Laemmli as previously described (8). Proteins were separated by $15 \%$ SDS-polyacrylamide gel electrophoresis (PAGE) and transferred by electroblotting onto Immobilon ${ }^{\circledR} \mathrm{P}$ membranes (Millipore, Bedford, MA, USA). Western immunoblotting was performed as previously reported using affinity-purified antibodies that recognize the neurofibromatosis 2 gene product, merlin (8). In COS-1 cells transfected with DNA prepared by ammonium acetate (lane 1) or anion-exchange chromatography (lane 2), C-terminal merlin protein was detected (Figure 1B). No merlin fragment overexpression was detected in untransfected COS- 1 cells or COS- 1 cells receiving pcDNA3 vector alone (data not shown).

Using COS-1 cells, we next demonstrated that DNA prepared using the ammonium acetate protocol is sufficient for transient reporter assays. In these experiments, COS- 1 cells were plated to $40 \%-50 \%$ confluency in 6well plates and transfected with a $\mathrm{LacZ}$ reporter gene (pCMV- $\beta$; Pharmacia Biotech, Piscataway, NJ, USA) as described above. After two days, cells were analyzed for transfection efficiency by $\beta$-galactosidase immunocytochemistry. Cells were washed twice in $1 \times$ PBS and fixed with $750 \mathrm{~mL}$ of $2 \%$ freshly made paraformaldehyde for 10 min at $4^{\circ} \mathrm{C}$. Following fixation, cells

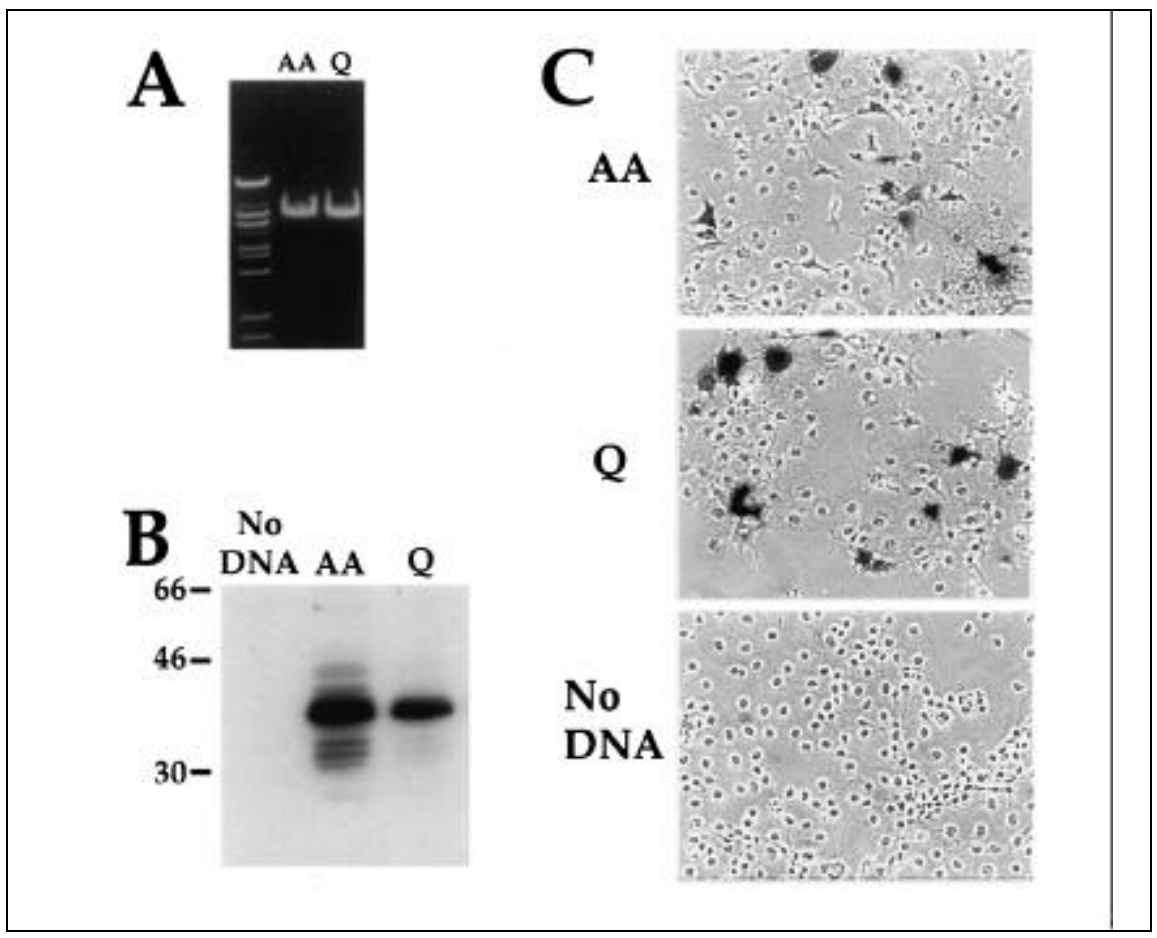

Figure 1. Comparison of DNA obtained by ammonium acetate and anion-exchange protocols. (A) $0.5 \mu \mathrm{g}$ of pCMV- $\beta$ purified using ammonium acetate (AA) or anion-exchange chromatography using QIAGEN-500 tips (Q) was digested with EcoRI overnight at $37^{\circ} \mathrm{C}$ and separated by $1 \%$ agarose gel electrophoresis in $1 \times$ TAE buffer. The predicted fragment of $7.2 \mathrm{~kb}$ was visualized by ethidium bromide staining. The position of the molecular size markers ( $\lambda B s t$ EII ladder) is shown on the left. (B) Western immunoblot analysis of COS-1 cells transiently transfected with pcDNA3.NF2.C-term DNA prepared by ammonium acetate or anion-exchange chromatography. Immunodetection was accomplished using affinity-purified WA28 rabbit polyclonal anti-merlin antibodies and the ECL ${ }^{\text {TM }}$ System (Amersham, Arlington Heights, IL, USA). The 35-kDa C-terminal merlin protein is detected in both samples. The positions of the molecular weight markers are shown on the left. (C) $\beta$-galactosidase development of COS-1 cells transiently transfected with pCMV- $\beta$ prepared by ammonium acetate or anion-exchange chromatography. The transfection efficiencies were roughly equivalent $(11.7 \% \pm 1.3 \%$ and $9.2 \% \pm 0.9 \%$ for Qiagen and ammonium acetate DNA, respectively). COS-1 cells transfected with no DNA are shown in the third panel (No DNA). Darkly stained cells were observed in both the Qiagen and ammonium acetate DNA transfections.

were again washed twice in $1 \times$ PBS and developed using the LacZ staining solution. The LacZ staining solution was prepared by prewarming $9.3 \mathrm{~mL}$ of $1 \times$ PBS containing $20 \mu \mathrm{L} 1 \mathrm{M} \mathrm{MgCl}_{2}$, $2 \mu \mathrm{L}$ Nonidet ${ }^{\circledR} \mathrm{P}-40$ and $10 \mu \mathrm{L} 10 \%$ sodium deoxycholate at $37^{\circ} \mathrm{C}$ for 10 min. To the prewarmed solution, 250 $\mu \mathrm{L}$ of $200 \mathrm{mM}$ ferrocyanide, $250 \mu \mathrm{L}$ of $20 \mathrm{mM}$ ferricyanide and $100 \mu \mathrm{L}$ of 50 $\mathrm{mg} / \mathrm{mL}$ 5-bromo-4-chloro-3-indolyl- $\beta$ D-galactopyranoside (X-gal) are added. This complete solution is added to the fixed cells and incubated, wrapped in aluminum foil, for $60 \mathrm{~min}$ at room temperature. The cells are then washed twice in $1 \times$ PBS and the transfection efficiency determined by counting the number of dark blue cells as a fraction of the total number of cells. DNA prepared by ammonium acetate or anionexchange chromatography resulted in similar transfection efficiencies (actual numbers). A representative transfection is shown in Figure 1C. Five fields of approximately 300 cells each were counted at $10 \times$ magnification. Transfection efficiencies of $11.7 \% \pm 1.3 \%$ and $9.2 \% \pm 0.9 \%$ were obtained for the Qiagen and ammonium acetate DNA preparations, respectively. Similar results were also observed with NIH-3T3 cells (data not shown).

The ammonium acetate protocol described in this report provides an inexpensive and nontoxic substitute for the cesium chloride and anion-exchange chromatography DNA preparation protocols. It has several advantages over the cesium chloride procedure including: (i) reduced material expense, (ii) reduced time required and (iii) use of nontoxic reagents. Likewise, the ammonium acetate protocol takes approximately the same time as the anion-exchange method but is significantly less expensive and results in much higher DNA yields. The application of this procedure to mammalian cell transfection will allow researchers to use this high-quality DNA to study protein function and gene expression in tissue culture cells.

\section{REFERENCES}

1.Andreason, G.L. and G.A. Evans. 1988. Introduction and expression of DNA molecules in eukaryotic cells by electroporation. 
BioTechniques 6:650-660.

2.Chen, C. and H. Okayama. 1987. High efficiency transformation of mammalian cells by plasmid DNA. Mol. Cell. Biol. 7:2745-2752.

3.Chu, G.H., H. Hayakawa and P. Berg. 1987.

Electroporation for the efficient transfection of mammalian cells with DNA. Nucleic Acids Res. 15:1311-1326.

4.Felgner, P.L., T.R. Gadek, M. Holm, R. Roman, H.W. Chan, M. Wenz, J.P. Northrop, G.M. Ringold and M. Danielsen. 1987. Lipofection: a highly efficient, lipid-mediated DNA transfection procedure. Proc. Natl. Acad. Sci. USA 84:7413-7417.

5.Hines, R.N., K.C. O'Connor, G. Vella and W. Warren. 1992. Large-scale purification of plasmid DNA by anion-exchange high-performance liquid chromatography. BioTechniques 12:430-434.

6.Lee, S.-y. and S. Rasheed. 1990. A simple procedure for maximum yield of high-quality plasmid DNA. BioTechniques 9:676-679.

7.Mannino, R.J. and S. Gould-Fogerite. 1988. Liposome mediated gene transfer. BioTechniques 6:682-690.

8.Scherer, S.S. and D.H. Gutmann. 1996. Expression of the neurofibromatosis 2 tumor suppressor gene product, merlin, in Schwann cells. J. Neurosci. Res. 46:595-605.

9.Wigler, M., S. Silverstein, L.-S. Lee, A. Pellicer, Y.-C. Cheng and R. Axel. 1977. Transfer of purified herpes virus thymidine kinase gene to cultured mouse cells. Cell 11:223-232.

We would like to thank the members of our laboratory, particularly Drs. Hua-mei $X u$ and Jenny $Y u$ for their critical reading of this manuscript and their contributions to the project. D.H.G. is supported by grants from the National Institutes of Health (Nos. NS01590-06 and NS33494-03). Address correspondence to David H. Gutmann, Department of Neurology, Washington University School of Medicine, Box 8111, 660 S. Euclid Avenue, St. Louis, MO 63110, USA. Internet: gutmannd@neuro.wustl.edu

Received 17 December 1996; accepted 3 March 1997.

Susan M. Saporito-Irwin, R. Todd Geist and David $H$. Gutmann

Washington University School of Medicine

St. Louis, MO, USA

\section{Rapid Purification of Reporter Group-Tagged Inositol Hexakisphos- phate on Ion-Exchange Membrane Adsorbers}

BioTechniques 23:427-430 (September 1997)

Ion-exchange (IEX) chromatography has been among the most frequently used chromatographic techniques for separation and purification of proteins, polypeptides, nucleic acids, polynucleotides and other charged biomolecules. The success of IEX is due to its widespread applicability, resolving power, high capacity and simplicity. Separation times can be reduced using HPLC, but at increased cost in materials and setup time. Alternatively, IEX can be accomplished using membrane adsorbers. We report a fast and efficient method of purification of two inositol hexakisphosphate $\left(\mathrm{InsP}_{6}\right)$ derivatives, one bearing a tritiated photoaffinity moiety and the other a fluorescent reporter group.

InsP $\mathrm{P}_{6}$, a ubiquitous constituent of plants, has been shown to be an antioxidant and possess anticancer properties (13). It occurs in mammalian tissues in substantial levels and has been reported to influence calcium flux and alter electrophysiological and cardiovascular events (1). InsP $_{6}$ binds synaptic vesicle proteins and may be an important regulator in synaptic vesicle docking during exocytosis and endocytosis (14).

Several affinity probes have been synthesized in our laboratory (11) to facilitate the isolation and characterization of $\mathrm{InsP}_{6}$-binding proteins. These proteins mediate biological activities such as binding to synaptotagmin domains (9), assembly proteins AP-2 (7) and AP-3 (16), and Golgi coatomer complexes (5), and act as substrates for $\mathrm{InsP}_{6}$ kinases (15). The probes used include photoaffinity $(4,11,12)$ and fluorescent labels (6), caged compounds (2) and affinity resins $(1,15)$.

Tethered benzophenone-containing photophores (4) have been successfully used as photoaffinity reagents for inositol phosphates $(11,12)$. They have traditionally been purified on a diethyl- 